\title{
Meta-cleavage enzyme gene tes $B$ is necessary for testosterone degradation in Comamonas testosteroni TA441
}

\author{
Masae Horinouchi, ${ }^{1}$ Takako Yamamoto, ${ }^{1}$ Katsuhiko Taguchi, ${ }^{1}$ \\ Hiroyuki Arai ${ }^{1}$ and Toshiaki Kudo ${ }^{1,2}$
}

\author{
Author for correspondence: Masae Horinouchi. Tel: +8148467 9545. Fax: +81484624672. \\ e-mail:masae@postman.riken.go.jp
}

RIKEN (The Institute of Physical and Chemical Research) ${ }^{1}$ and JST2, 2-1 Hirosawa, Wako-shi, Saitama 351-0198, Japan

\begin{abstract}
Comamonas testosteroni metabolizes testosterone as the sole carbon source via a meta-cleavage reaction. A meta-cleavage enzyme gene, tes $B$, was cloned from $\mathrm{C}$. testosteroni TA441. The deduced $\mathrm{N}$-terminal amino acid sequence of tes $B$ matched that of the purified meta-cleavage enzyme which is induced in TA441 during growth on testosterone as the sole carbon source. The tesBdisrupted mutant did not show growth on testosterone, suggesting that tes $B$ is necessary for TA441 to grow on testosterone. Downstream from tesB, three putative ORFs which encode products also necessary for growth of TA441 on testosterone were identified. The usual substrate of TesB is probably 3,4dihydroxy-9, 10-secoandrosta-1,3,5(10)-triene-9,17-dione. Although this compound was not identified in the gene disrupted mutants, accumulation of upstream metabolites of testosterone degradation, 4-androstene-3,17-dione and 1,4-androstadiene-3,17-dione, was shown by TLC analysis.
\end{abstract}

Keywords: biodegradation, steroid hormone, seco-steroid

\section{INTRODUCTION}

Steroids are widespread in the environment, found as cholesterol, cholic acid, the sex and adrenal cortical hormones of mammals, and phytosterols in plants. In the environment, micro-organisms are considered to play a principal role in steroid degradation. Degradation of steroids such as testosterone by micro-organisms has attracted interest as a means to produce steroid hormone derivatives for use as hormonal drugs. In steroiddegrading micro-organisms, the catabolic enzymes for steroid degradation are usually not constitutively expressed but rather are induced by their respective substrates. Comamonas testosteroni is a Gram-negative bacterium which is able to grow using certain $\mathrm{C}_{19}$ and $\mathrm{C}_{21}$ steroids as well as many other aromatic compounds as the sole carbon and energy source. C. testosteroni metabolizes certain steroids through a complex metabolic pathway involving many enzymic steps and the synthesis of these enzymes is induced by certain steroids (Florin et al., 1996; Möbus et al., 1997; Möbus \&

Abbreviation: $\mathrm{Km}$, kanamycin.

The GenBank/EMBL/DDBJ accession number for the sequence reported in this paper is $A B 040808$.
Maser, 1998). Degradation of testosterone in C. testosteroni is considered to be initiated by dehydrogenation of the $17 \beta$-hydroxyl group to 4 -androstene3,17-dione (reaction 1 in Fig. 1) (Abalain et al., 1993; Genti-Raimondi et al., 1991), followed by desaturation of the A ring (Fig. 1). A pathway for degradation of 4androstene-3,17-dione in C. testosteroni was proposed by Coulter \& Talalay (1968), based on analysis of the compounds produced in culture of testosterone-grown C. testosteroni. In the degradation pathway, 4androstene-3,17-dione undergoes $\Delta^{1}$-dehydrogenation (reaction 2 in Fig. 1) and $9 \alpha$-hydroxylation to produce $9 \alpha$-hydroxy-1,4-androstadiene-3,17-dione (compound II and reaction 3 in Fig. 1), then it is converted to 3-hydroxy-9,10-secoandrosta-1,3,5(10)-triene-9,17dione (Coulter \& Talalay, 1968). This compound is hydroxylated at the C-4 position to yield 3,4-dihydroxy9,10-secoandrosta-1,3,5(10)-triene-9,17-dione (Fig. 1), which is cleaved between C-4 and C-5 through a metacleavage reaction (Sih et al., 1966). A number of the genes encoding enzymes involved in the degradation pathway of C. testosteroni have been identified in studies performed in the 1990s. The gene for the $17 \beta$-dehydrogenase, which catalyses the initial dehydrogenation reaction (reaction 1 in Fig. 1), has been cloned and characterized (Abalain et al., 1993; Genti-Raimondi et 

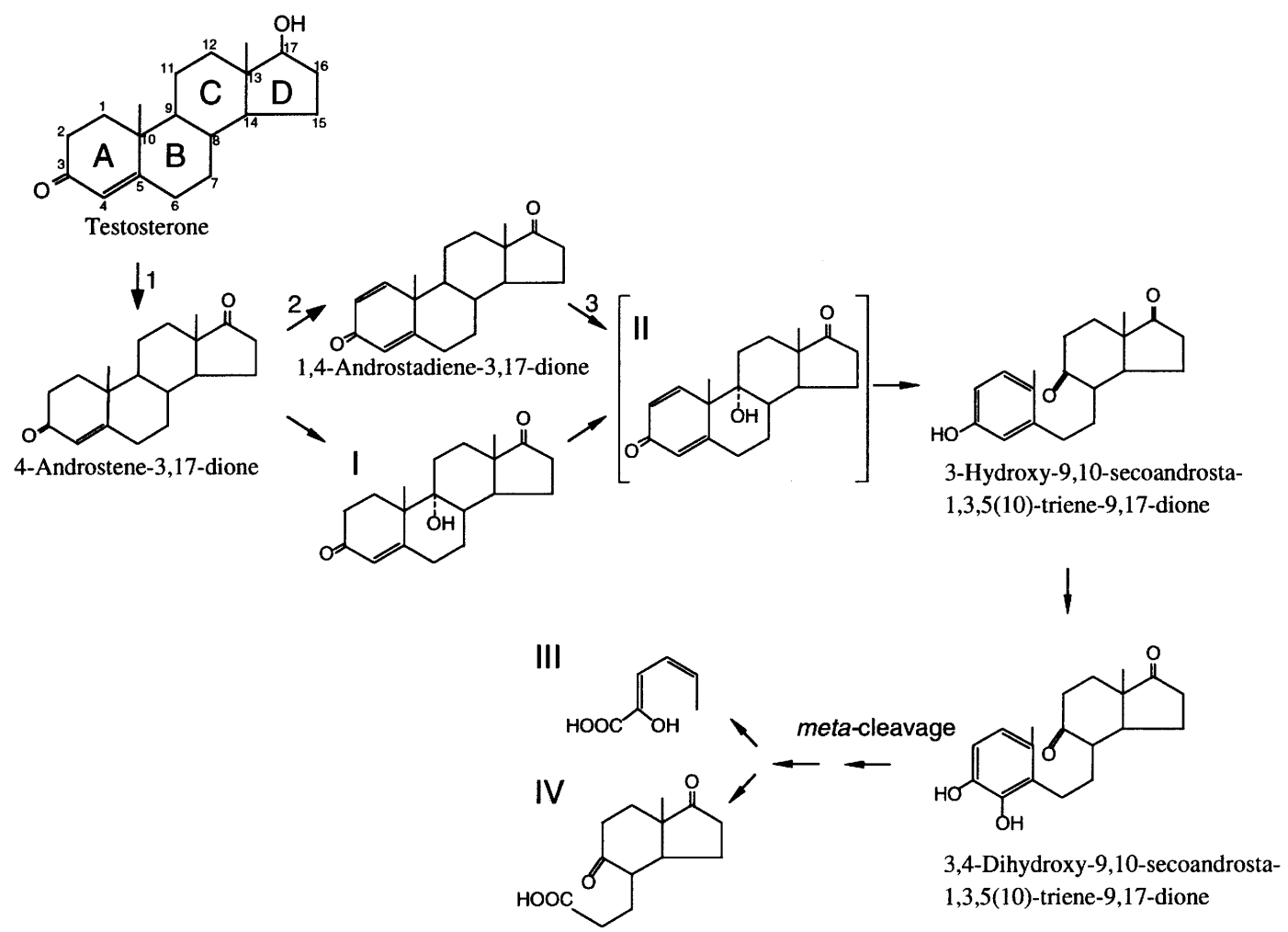

Fig. 1. Proposed testosterone degradation pathway in C. testosteroni (Coulter \& Talalay, 1968). Compound I, $9 \alpha$-hydroxy4-androstene-3,17-dione; II, $9 \alpha$-hydroxy-1,4-androstadiene-3,17-dione; III, 2-oxo-cis-4-hexenoic acid; IV, 3a $\alpha, 4 \beta, 5,6,7,7 \mathrm{a}$ hexahydro-7a $\beta$-methyl-1,5-dioxo-4-indanpropionic acid. The enzyme for reaction 1 is $17 \beta$-dehydrogenase; $2, \Delta^{1}$-dehydrogenase.

al., 1991). $\Delta^{1}$-Dehydrogenase and $\Delta^{4}(5 \alpha)$-dehydrogenase, which belong to the same transcription unit in $C$. testosteroni ATCC 17410, introduce a double bond into the A ring of 4-androstene-3,17-dione and 1-androstene3,17-dione, respectively, to produce 1,4-androstadiene3,17-dione (reaction 2 in Fig. 1; 1-androstene-3,17-dione is not indicated in Fig. 1) (Florin et al., 1996; Plesiat et al., 1991). In addition to these dehydrogenases, the genes for $3 \alpha$-hydroxysteroid hydrogenase and $\Delta^{5-3}$ ketosteroid isomerase from C. testosteroni have also been cloned and characterized (Abalain et al., 1995; Möbus \& Maser, 1998; Kuliopulos et al., 1987; Choi \& Benisek, 1988). Recently, the N-terminal sequences of about ten testosterone-inducible proteins have been determined (Möbus et al., 1997). Some of them show high homology with catabolic enzymes involved in degradation of aromatic compounds, such as BphC, a meta-cleavage enzyme involved in biphenyl degradation (for example see Furukawa et al., 1987; Kimbara et al., 1989; Hofer et al., 1993).

C. testosteroni TA441 was isolated from a termite, an organism which is well known as an effective wood degrader. TA441 has the ability to grow on aromatic compounds such as phenols, 3-(3-hydroxyphenyl)-propionic acid and their derivatives. TA441 can also utilize testosterone and some other steroids as the sole carbon and energy source. The aph genes and $m b p$ genes, which code for enzymes involved in the degradation of phenols and 3-(3-hydroxyphenyl)-propionic acid in TA441, have previously been identified and characterized (Arai et al., 1998, 1999), whereas the genes encoding the enzymes involved in testosterone degradation have not yet been characterized. Cultures of TA441 show a yellow colour during growth on testosterone. This yellow colour suggests that testosterone degradation proceeds via a meta-cleavage reaction. TA441 has at least two metacleavage enzymes, $a p h B$ and $m h p B$. As an $a p h B^{-} m h p B^{-}$ double mutant of strain TA441 has been found to retain the ability to grow on testosterone and showed metacleavage activity (unpublished data), another metacleavage enzyme for testosterone degradation is therefore expected to exist.

In this paper, we report the cloning of the gene for the meta-cleavage enzyme which is produced during growth on testosterone and is necessary for testosterone degradation in TA441. The cloning of genes encoding three other proteins necessary for testosterone degradation, located downstream from the gene for the meta-cleavage enzyme, is also described.

\section{METHODS}

Bacterial strains, plasmids and culture conditions. Bacterial strains and plasmids used in this study are listed in Table 1. Escherichia coli JM109 was used as the host strain for DNA 
Table 1. Bacterial strains and plasmids used in this study

Ap; ampicillin, $\mathrm{Km}$; kanamycin, Tc; tetracycline.

\begin{tabular}{|c|c|c|}
\hline Strain or plasmid & Characteristics & Source or reference \\
\hline \multicolumn{3}{|l|}{ Strains } \\
\hline C. testosteroni TA441 & Wild-type, Tes & Arai et al. (1998) \\
\hline $\mathrm{TesB}^{-}$ & tes $B:: \mathrm{Km}^{\mathrm{r}}$ mutant of TA441 & This work \\
\hline $\mathrm{ORF}^{-}$ & ORF1:: $\mathrm{Km}^{\mathrm{r}}$ mutant of TA441 & This work \\
\hline $\mathrm{ORF}^{-}$ & ORF $2:: \mathrm{Km}^{\mathrm{r}}$ mutant of TA441 & This work \\
\hline $\mathrm{ORF}^{-}$ & ORF3:: $\mathrm{Km}^{\mathrm{r}}$ mutant of TA441 & This work \\
\hline \multicolumn{3}{|l|}{ Plasmids } \\
\hline pUC19 & $\mathrm{Ap}^{\mathrm{r}}$, lacZ & Vieira \& Messing (1987) \\
\hline pCPY & $\mathrm{Ap}^{\mathrm{r}}$, pUC19 with $4.3 \mathrm{~kb}$ Pst I insert of C. testosteroni TA441 & This work \\
\hline pCP31 & $\mathrm{Ap}^{\mathrm{r}}, \mathrm{pUC19}$ with PstI-KpnI insert from pCPY & This work \\
\hline pCP311 & $\mathrm{Ap}^{\mathrm{r}}, \mathrm{pUC19}$ with PstI-ApaI insert from $\mathrm{pCPY}$ & This work \\
\hline pTesB-Km ${ }^{r}$ & $\mathrm{Ap}^{\mathrm{r}}, \mathrm{pCP} 311$ derivative with Km-resistance gene in EcoRV site of tesB & This work \\
\hline pCP312 & $\mathrm{Ap}^{\mathrm{r}}$, pUC19 with $A p a \mathrm{I}-E c o \mathrm{RI}$ insert from pCPY & This work \\
\hline pORF1-Km ${ }^{r}$ & $\mathrm{Ap}^{\mathrm{r}}$, pCP31 derivative with Km-resistance gene in EcoRV site of ORF1 & This work \\
\hline pORF2-Km ${ }^{\mathrm{r}}$ & $\mathrm{Ap}^{\mathrm{r}}, \mathrm{pCP} 31$ derivative with $\mathrm{Km}$-resistance gene in SacII site of ORF2 & This work \\
\hline pORF3-Km ${ }^{r}$ & $\mathrm{Ap}^{\mathrm{r}}, \mathrm{pCP} 312$ derivative with $\mathrm{Km}$-resistance gene in BamHI site of ORF3 & This work \\
\hline pRWTesB & $\mathrm{Tc}^{\mathrm{r}}, \mathrm{pR} \mathrm{W} 2$ derivative carrying the same insert as pCP311 & This work \\
\hline pRWTesBp & $\mathrm{Tc}^{\mathrm{r}}, \mathrm{pRW} 2$ derivative with $640 \mathrm{bp}$ PstI insert of pCP31 & This work \\
\hline
\end{tabular}

manipulations. E. coli transformants were grown on LB medium at $37^{\circ} \mathrm{C}$. For plate cultures, $1.6 \%(\mathrm{w} / \mathrm{v})$ agar was added to the media. Ampicillin $\left(100 \mathrm{mg} \mathrm{l}^{-1}\right)$ was added for growth of transformants harbouring pUC19 derivative plasmids, tetracycline $\left(5 \mathrm{mg} \mathrm{l}^{-1}\right)$ was added for growth of transformants harbouring pRW2 derivative plasmids, and kanamycin $(\mathrm{Km}) \quad\left(30 \mathrm{mg} \mathrm{l}^{-1}\right)$ was added for growth of transformants harbouring plasmids containing the Km-resistance gene originating from pSUP5011. IPTG $(100 \mathrm{mM})$ and X-Gal $\left(20 \mathrm{mg} \mathrm{l}^{-1}\right)$ were added for colour selection. Comamonas testosteroni strains were grown at $30{ }^{\circ} \mathrm{C}$ in $\mathrm{LB}$ medium or C medium (Arai et al., 1998) with suitable carbon sources. Carbon sources (testosterone, 1,4-androstadiene3,17-dione or $p$-hydroxybenzoate) were added as a filtered DMSO solution at a final concentration of $0 \cdot 1 \%(\mathrm{w} / \mathrm{v})$. Growth of TA441 was monitored by counting colonies that appeared on LB plates, on which appropriately diluted cultures had been spread, after incubation at $30^{\circ} \mathrm{C}$. $\mathrm{Km}$ was added to media at $400 \mathrm{mg} \mathrm{l}^{-1}$ to select recombinant strains of TA441, and a combination of $800 \mathrm{mg} \mathrm{Km} \mathrm{l}^{-1}$ and $300 \mu \mathrm{g}$ carbenicillin $\mathrm{l}^{-1}$ was added for further selection.

Partial purification and determination of the $\mathrm{N}$-terminal amino acid sequence of TesB. C. testosteroni TA441 cells grown in testosterone-containing medium were centrifuged, resuspended in $10 \mathrm{mM}$ potassium phosphate buffer $(\mathrm{pH} 7 \cdot 5)$ and disrupted by sonication (Branson, TW3). The cell suspension was then centrifuged and the supernatant was applied to a DEAE ion-exchange column equilibrated with phosphate buffer. A protein fraction showing a yellow colour, corresponding to the meta-cleavage product of 2,3dihydroxybiphenyl, was eluted with phosphate buffer containing $150 \mathrm{mM} \mathrm{NaCl}$. 2,3-Dihydroxybiphenyl was used instead of the proposed substrate [3,4-dihydroxy-9,10secoandrosta-1,3,5(10)-triene-9,17-dione in Fig. 1], which was not commercially available. The enzyme in the fraction showing a yellow colour was partially purified by means of a Superose-12 gel filtration column and a Mono-Q HR 5/5 column using the Pharmacia LKB Biotechnology fast protein liquid chromatography system. The partially purified enzyme was run on a nondenaturing $12 \%$ acrylamide gel. The gel was stained with 2,3-dihydroxybiphenyl and a band showing a yellow colour corresponding to the meta-cleavage product was transferred to a PVDF membrane. The amino terminal sequence was determined by automated Edman degradation using the Applied Biosystems model 492 protein sequencing system.

DNA manipulation. Plasmid DNA was prepared from the $E$. coli host strain by the alkaline lysis method (Birnboim \& Doly, 1979). Restriction endonucleases, the DNA ligation kit version 2 (Takara Shuzo) and the DNA blunting kit (Takara Shuzo) were used according to the manufacturer's instructions. DNA fragments were extracted by the glass powder method (GeneClean II kit, Bio101) as instructed by the manufacturer. Other DNA manipulations were performed according to standard methods (Sambrook et al., 1989).

Cloning of genes encoding meta-cleavage enzymes. Total DNA of strain TA441 was digested with Pst I and ligated to pUC19 vector which had been digested with PstI and treated with shrimp alkaline phosphatase (Roche Molecular Biochemicals). E. coli JM109 was transformed with the resultant plasmids according to the method of Hanahan (1983). Ampicillin-resistant transformants were selected on LB agar plates. Transformants with meta-cleavage activity were selected on the basis of yellow pigmentation after spraying them with 2,3-dihydroxybiphenyl (50 $\mathrm{mM}$ in acetone).

Nucleotide sequence determinations. Deletion libraries of the reconstructed plasmids were generated using a DNA deletion kit (Takara Shuzo). DNA sequences were determined using an ABI model 373A automated DNA sequencer and the dye terminator sequencing protocols (Perkin-Elmer). The templates for dideoxy chain-termination reactions were prepared using the Wizard Plus Minipreps DNA Purification System (Promega). Both strands of the DNA were sequenced and the 
nucleotide sequences of linking junctions of the fragments were determined using custom-designed oligonucleotides as primers. Alignment of the meta-cleavage enzyme and related proteins was performed according to the method of Higgins \& Sharp (1989) with the PAM matrix of Dayhoff et al. (1978).

Construction of plasmids and mutant strains. Plasmid pSKKm ${ }^{\mathrm{r}}$ was constructed by ligating a HindIII-SalI fragment of pSUP5011, containing a Km-resistance gene, with HindIIIand SalI-treated pBluescript KS - . The tesB gene in pCP311 was disrupted by insertion of a SmaI fragment from pSKKm ${ }^{\mathrm{r}}$, containing the $\mathrm{Km}$-resistance gene, into the EcoRV site in tes $B$. The resultant plasmid, $\mathrm{pTesB}-\mathrm{Km}^{\mathrm{r}}$, which encodes the $\mathrm{Km}$-resistance gene in the same transcriptional direction as tes $B$, was used for inactivation of the tesB gene in TA441 by homologous recombination according to the method described previously (Arai et al., 1998). A Km-resistant and carbenicillin-sensitive TA441 mutant was selected and designated strain $\mathrm{TesB}^{-}$. Insertion of the $\mathrm{Km}$-resistance gene into the chromosome of $\mathrm{TesB}^{-}$was confirmed by hybridization using the Km-resistance gene and tes $B$ as probes. ORFs 1, 2 and 3 in TA441 were individually disrupted in the same way. The Km-resistance gene was inserted into the EcoRV site in ORF1, the SacII site in ORF2 and the BamHI site in ORF3 (see Fig. 3).

Growth of TA441 and mutant strains on testosterone. TA441 and mutant strains were grown at $30^{\circ} \mathrm{C}$ in $5 \mathrm{ml} \mathrm{LB}$ medium for about $15 \mathrm{~h}$. The cells were centrifuged and the pellet was resuspended in $\mathrm{C}$ medium at an $\mathrm{OD}_{600}$ of 10 . A $50 \mu$ l portion of the resultant cell suspension was transferred as inoculum into $10 \mathrm{ml} \mathrm{C}$ medium supplemented with $0 \cdot 1 \%$ (w/v) testosterone or $p$-hydroxybenzoate (positive control) as the sole carbon source and incubated at $30^{\circ} \mathrm{C}$ for $24 \mathrm{~h}$. The extent of growth was determined every $3 \mathrm{~h}$; colonies that appeared on LB plates on which appropriately dilutions of the culture had been spread were counted after incubation at $30{ }^{\circ} \mathrm{C}$ for about $15 \mathrm{~h}$. When several kinds of mutants were used (see Fig. 6 and Table 2), a $100 \mu$ l portion was used as inoculum.

Promoter activity. TA441 was transformed with pRWtesBp carrying the transcriptional fusion construct tes $B:$ : lac $Z$. The plasmid pRWtesBp is a broad-host-range plasmid pRW2 derivative encoding 640 bp PstI fragment of TA441 total DNA (see Fig. 3). TA441(pRWtesBp) cells grown overnight in LB medium with $5 \mathrm{mg}$ tetracycline $\mathrm{l}^{-1}$ were washed twice and resuspended in $\mathrm{C}$ medium at an $\mathrm{OD}_{600}$ of 10 . A $200 \mu$ l portion of the resultant cell suspension was transferred as inoculum into $100 \mathrm{ml} \mathrm{C}$ medium containing $0 \cdot 1 \%$ testosterone, 1,4androstene-3,17-dione or $p$-hydroxybenzoate (negative control) with $5 \mathrm{mg}$ tetracycline $1^{-1}$ and incubated at $30^{\circ} \mathrm{C}$. Changes in the activity of $\beta$-galactosidase, the lac $Z$ gene product, were monitored every $2 \mathrm{~h}$. The activity of $\beta$ galactosidase was measured by the protocol described by Miller (1992). Before $A_{420}$ and $A_{500}$ were measured, centrifugation was needed to remove testosterone or 1,4-androstene3,17-dione. To measure $\mathrm{OD}_{660}$, these compounds were removed from the culture by ethyl acetate extraction. The cells were collected by centrifugation and resuspended in the same volume of water.

TLC. Cultures grown for $24 \mathrm{~h}$ in the experiment shown in Fig. 5 were used for TLC analysis. The culture was extracted with a half volume of ethyl acetate, subjected to TLC (kieselgel 60 F254 plate, Merck KgaA) using benzene/methanol (19:1, v/v) as the solvent system and detected by UV absorption at $254 \mathrm{~nm}$. Testosterone, 4-androstene-3,17-dione and 1,4androstadiene-3,17-dione were used as standards.

\section{RESULTS AND DISCUSSION}

\section{$\mathrm{N}$-terminal sequence of the testosterone-inducible meta-cleavage enzyme}

TA441 cultures became yellow in colour when the organism was grown with testosterone as the sole carbon source. This yellow colour suggests that TA441 degrades testosterone via a meta-cleavage reaction. Our preliminary experiments showed that TA441 had a metacleavage enzyme which is produced when TA441 is grown on testosterone, in addition to the meta-cleavage enzymes already characterized in this strain $(a p h B$ and $m h p B$ ) (Arai et al., 1998, 1999), and that the $a p h B^{-}$ $m h p B^{-}$double knock-out mutant of TA441 still retained the ability to utilize testosterone as the sole carbon source. From these results, we considered that a metacleavage enzyme different from AphB and MhpB was involved in testosterone degradation in TA441, and we proceeded to partially purify the protein and determine the $\mathrm{N}$-terminal sequence of the enzyme, as described in Methods. The sequence (MMEIRGLAYVVAESSDLDRWVSYARDVLG) was not identical to the N-terminal sequences of $\mathrm{AphB}$ or $\mathrm{MhpB}$; it was identical to the $\mathrm{N}$ terminal sequence of the testosterone-inducible protein TIP1 of C. testosteroni ATCC 11996 (Möbus et al., 1997). Cell-free extracts of TA441 cells grown with testosterone or with other compounds were analysed by PAGE and stained with 2,3-dihydroxybiphenyl (Fig. 2). The band corresponding to this meta-cleavage enzyme was not observed when TA441 cells were grown in the absence of testosterone.

\section{Cloning of the meta-cleavage enzyme gene}

E. coli JM109 was transformed with recombinant plasmids comprising a genomic library of strain TA441 and ampicillin-resistant transformants which showed

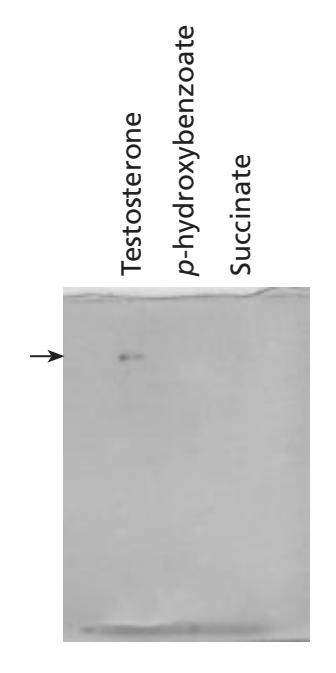

Fig. 2. PAGE of the cell-free extract of TA441 cells grown with testosterone, $p$-hydroxybenzoate or succinate. The gel was stained with 2,3-dihydroxybiphenyl and the meta-cleavage enzyme is presented with a yellow colour in the original gel. 


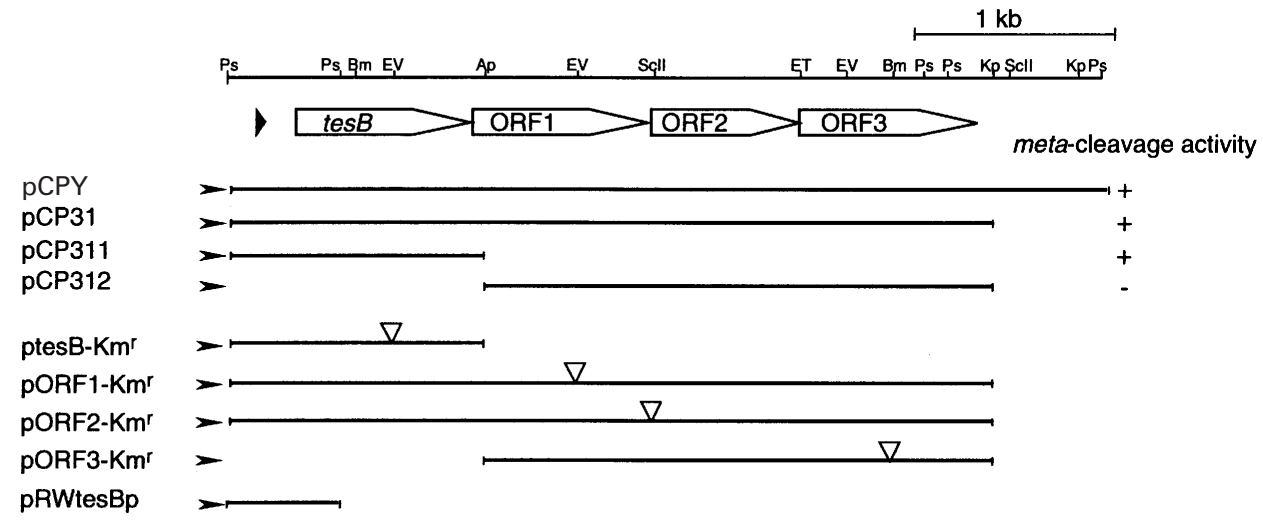

Fig. 3. Partial restriction map of a $4.5 \mathrm{~kb}$ Pstl fragment, the insert in $\mathrm{pCPY}$, encoding the testosterone-degrading enzyme genes of $C$. testosteroni TA441. The meta-cleavage enzyme gene tes $B$ and putative ORFs are indicated by large white arrows. The black arrowhead indicates the promoter sequence. Deletion plasmids are indicated below the restriction

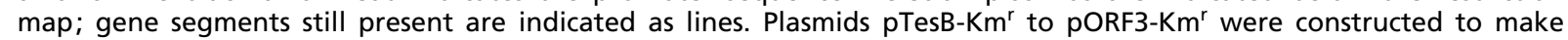
gene-disrupted mutants. Restriction sites where the $\mathrm{Km}$ resistance gene was inserted are indicated by small white arrowheads. The small black arrowheads indicate the direction of transcription regulated by the lac promoter of the pUC19 vector. Abbreviations are: Ap, Apal; Bm, BamHI; Bgll, Bg/ll; ERI, EcoRI; EV, EcoRV; ET, EcoT22I; Kp, Kpnl; Nr, Nrul; Ps, Pstl; Scl, Sacl; Scll, Sacll; Xb, Xbal. The accession number of this sequence is AB040808.

yellow pigmentation attributable to meta-cleavage of 2,3-dihydroxybiphenyl were selected. 2,3-Dihydroxybiphenyl was used instead of 3,4-dihydroxy-9,10secoandrosta-1,3,5(10)-triene-9,17-dione (Fig. 1), which was not commercially available. Meta-cleavage enzymes usually have broad substrate specificity, and in the case of strain TA441, the meta-cleavage activity of 2,3dihydroxybiphenyl was observed when the cells were grown in the presence of testosterone, but not succinate (data not shown). Among the selected transformants, one transformant was found by hybridization to harbour a plasmid which showed homology with an oligonucleotide based on the $\mathrm{N}$-terminal sequence of the testosterone-inducible meta-cleavage enzyme (ATGATGGAGATCCGCGGCCTGGCCTACGTGGTGGCCGA) and the restriction map of the DNA insert differed from that of $a p h B$ or $m h p B$. These results suggested that the cloned meta-cleavage enzyme gene was the expected one. This plasmid was designated pCPY. Other transformants showing the yellow colour were found to carry plasmids encoding $a p h B$ or $m h p B$. Fig. 3 shows the restriction map of the $4.5 \mathrm{~kb}$ pCPY insert; the region constituting the structural gene for the meta-cleavage enzyme was identified by examination of the activity displayed by each of a series of deletion mutants. Among them, a transformant carrying pCP311, which contained a $1.3 \mathrm{~kb}$ Pst $\mathrm{I}-A p a \mathrm{I}$ fragment, showed meta-cleavage activity (Fig. 3 ).

\section{Nucleotide sequence of the meta-cleavage enzyme gene}

We determined the nucleotide sequence of the $1.3 \mathrm{~kb}$ PstI-ApaI insert in pCP311 and identified an ORF by computer analysis. The deduced $\mathrm{N}$-terminal amino acid sequence of this ORF matched that of the purified testosterone-inducible meta-cleavage enzyme exactly.

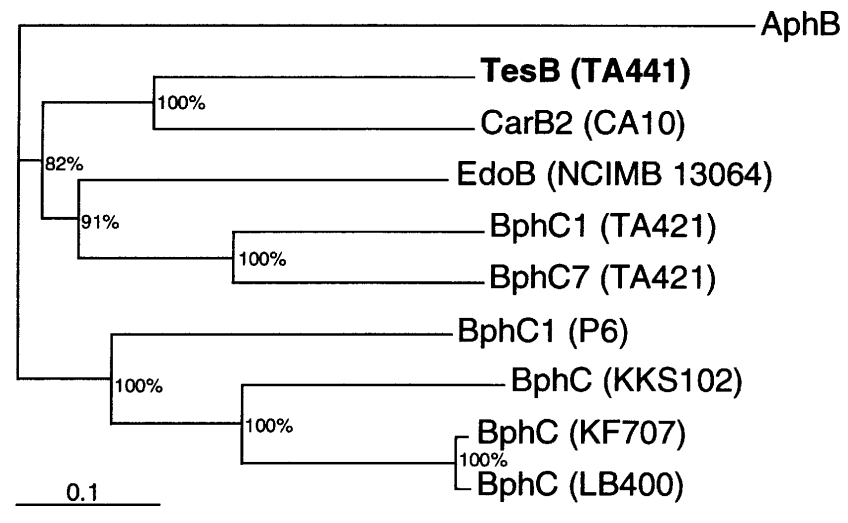

Fig. 4. Phylogenetic tree for TesB and meta-cleavage enzymes for 2,3-dihydroxybiphenyl. The tree was constructed using CLUSTAL $W$ with the PAM matrix. AphB, a meta-cleavage enzyme for catechol in C. testosteroni TA441, is used as an outgroup. Abbreviations are: CarB2, CarB2 of Pseudomonas sp. strain CA10 (Sato et al., 1997) (accession no. D89065); EdoB, EdoB of Rhodococcus rhodochrous NCIMB 13064 (Kulakov et al., 1998) (AJ003244); BphC1 (TA421), BphC1 of Rhodococcus sp. TA421 (Kosono et al., 1997) (D88013); BphC7, BphC7 of Rhodococcus sp. TA421 (Kosono et al., 1997) (D88019); BphC1 (P6), BphC1 of R. globerulus P6 (Asturias et al., 1994) (P47231); BphC (KKS102), BphC of Pseudomonas sp. strain KKS102 (Kimbara et al., 1989) (M26433); BphC (KF707), BphC of P. pseudoalcaligenes KF707 (Furukawa et al., 1987) (P08695); BphC (LB400), BphC of Burkholderia cepacia LB400 (Hofer et al., 1993) (P47228). Identities (\%) between TesB and the meta-cleavage enzymes are: CarB2, 55; EdoB, 46; BphC1 (TA421), 42; BphC7, 42; BphC1 (P6), 42; BphC (KKS102), 39; BphC (KF707), 41; BphC (LB400), 42.

As this result and the results of experiments involving gene disruption, described below, strongly indicated that the cloned meta-cleavage enzyme was involved in testosterone degradation in TA441, we named this gene 


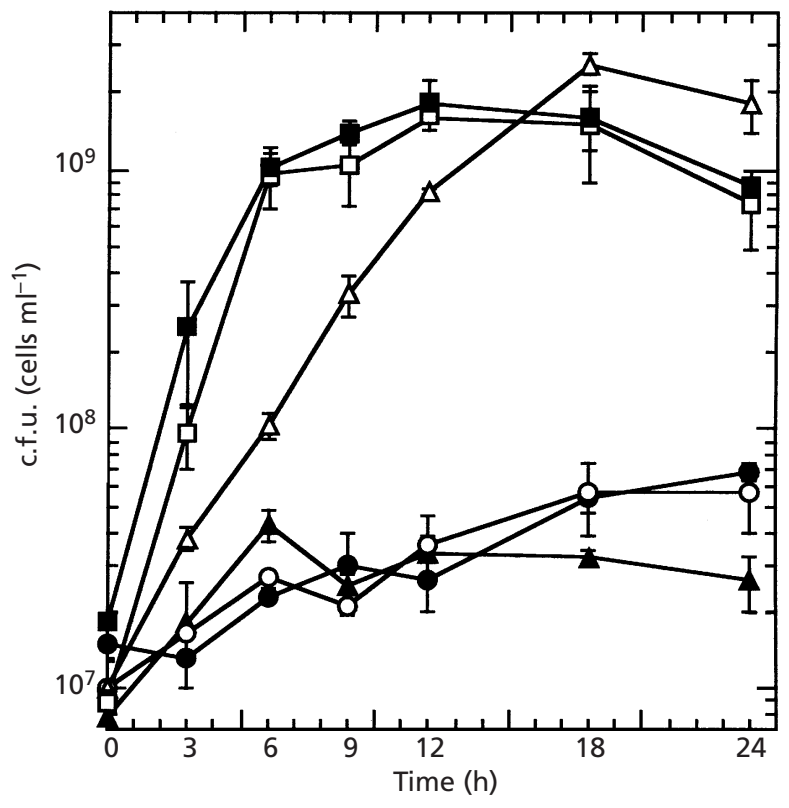

Fig. 5. Growth of TA441 and TesB ${ }^{-}$on testosterone as the sole carbon source. The strains were grown in $10 \mathrm{ml} \mathrm{C}$ medium supplemented with $0.1 \%(\mathrm{w} / \mathrm{v})$ testosterone (TA441, $\triangle$; TesB ${ }^{-}$, $\Delta$ ), -hydroxybenzoate (TA441, $\square$; TesB ${ }^{-}, \boldsymbol{D}$ ) (positive control) or without any carbon source (TA441, $\mathrm{O} ; \mathrm{TesB}^{-}, \mathbf{0}$ ) (negative control).

tes $B$. The deduced amino acid sequence of tes $B$ showed the most similarity ( $55 \%$ identity) to CarB2, a metacleavage enzyme from Pseudomonas sp. CA10 (Sato et al., 1997). TesB also showed $46 \%$ identity with EdoB from Rhodococcus rhodochrous NCIMB 13064 (Kulakov et al., 1998) and 39-42\% identity with BphCs from Rhodococcus and Pseudomonas sp. strains. A phylogenetic tree for TesB and these meta-cleavage enzymes is shown in Fig. 4. BphC1 from Rhodococcus globerulus P6 (Asturias et al., 1994), Pseudomonas sp. strain KKS102 (Kimbara et al., 1989), Pseudomonas pseudoalcaligenes KF707 (Furukawa et al., 1987) and Burkholderia cepacia LB400 (Hofer et al., 1993) are meta-cleavage enzymes in the biphenyl degradation pathway which utilize 2,3-dihydroxybiphenyl as a sub- strate, whereas the substrates of CarB2, EdoB, BphC1 and BphC7 from Rhodococcus sp. TA421 (Kosono et al., 1997) have not yet been identified. The phylogenetic tree for TesB and the meta-cleavage enzymes implies that these enzymes are divided into two groups: BphCs and the other meta-cleavage enzymes whose substrates are unknown. Conserved motifs in BphC, three amino acid residues functioning as metal-binding ligands $\left(\mathrm{H}_{146}\right.$, $\mathrm{H}_{213}$ and $\left.\mathrm{E}_{264}\right)$ and three involved in active sites $\left(\mathrm{H}_{198}\right.$, $\mathrm{H}_{244}$ and $\mathrm{Y}_{254}$ ) (Han et al., 1995), are also conserved in TesB.

\section{Disruption of tesB in TA441 and growth of the mutant on testosterone}

To confirm that TesB is necessary for testosterone metabolism in TA441, tesB in TA441 was disrupted with a Km-resistance gene by homologous recombination. Insertion of the Km-resistance gene into tes $B$ in the mutant strain was confirmed by hybridization (data not shown), and the resultant TesB mutant strain was designated $\mathrm{TesB}^{-}$. The results obtained by comparing the growth of $\mathrm{TesB}^{-}$and TA441 on testosterone as the sole carbon source are shown in Fig. 5. With $p$-hydroxybenzoate, which is metabolized by Mhp proteins, as the sole carbon source, $\mathrm{TesB}^{-}$grew as well as TA441, whereas with testosterone as the sole carbon source, the growth of the mutant was negligible, the same as the growth observed without any carbon source. The absence of significant growth of $\mathrm{TesB}^{-}$on testosterone indicates that TesB is necessary for growth of TA441 on testosterone. The ability to grow on testosterone was partially recovered in the $\mathrm{TesB}^{-}$mutant harbouring pRWtesB, a derivative of a broad-hostrange plasmid pRW2 encoding TesB (Table 2). From this result, it is confirmed that the reduction of the growth of $\mathrm{TesB}^{-}$mutant on testosterone was not caused by a polar effect.

\section{Sequence analysis of genes downstream from tes $B$}

As tes $B$ is necessary for testosterone degradation in TA441, gene segments downstream from tes $B$ were characterized. The DNA sequence of the insert in pCPY (Fig. 3) was found to contain three putative ORFs just

Table 2. Growth of mutant strains on testosterone

The extent of growth was determined at the beginning of the cultivation period and after about 24,48 and $72 \mathrm{~h}$. The data are the mean of more than three independent experiments.

\begin{tabular}{|c|c|c|c|c|c|}
\hline \multirow[t]{2}{*}{ Strain } & \multirow[t]{2}{*}{ Plasmid } & \multicolumn{4}{|c|}{ c.f.u. (SE) (cells ml ${ }^{-1}$ ) } \\
\hline & & $0 \mathrm{~h}$ & $24 \mathrm{~h}$ & $48 \mathrm{~h}$ & $72 \mathrm{~h}$ \\
\hline TA441 & - & $2 \cdot 7 \times 10^{7}\left(9 \cdot 4 \times 10^{6}\right)$ & $2 \cdot 6 \times 10^{9}\left(2 \cdot 8 \times 10^{8}\right)$ & - & - \\
\hline $\mathrm{TesB}^{-}$ & pRWTesB & $9 \cdot 8 \times 10^{6}\left(2 \cdot 1 \times 10^{6}\right)$ & $7 \cdot 7 \times 10^{7}\left(1 \cdot 1 \times 10^{7}\right)$ & $2 \cdot 6 \times 10^{8}\left(2 \cdot 6 \times 10^{7}\right)$ & - \\
\hline $\mathrm{TesB}^{-}$ & - & $4.3 \times 10^{7}\left(1 \cdot 6 \times 10^{7}\right)$ & $7 \cdot 7 \times 10^{7}\left(1 \cdot 7 \times 10^{7}\right)$ & - & $7 \cdot 3 \times 10^{7}\left(3 \cdot 4 \times 10^{7}\right)$ \\
\hline ORF1- & - & $2 \cdot 7 \times 10^{7}\left(6 \cdot 4 \times 10^{5}\right)$ & $1.4 \times 10^{8}\left(3 \cdot 1 \times 10^{7}\right)$ & - & $1 \cdot 9 \times 10^{8}\left(4 \cdot 0 \times 10^{7}\right)$ \\
\hline
\end{tabular}




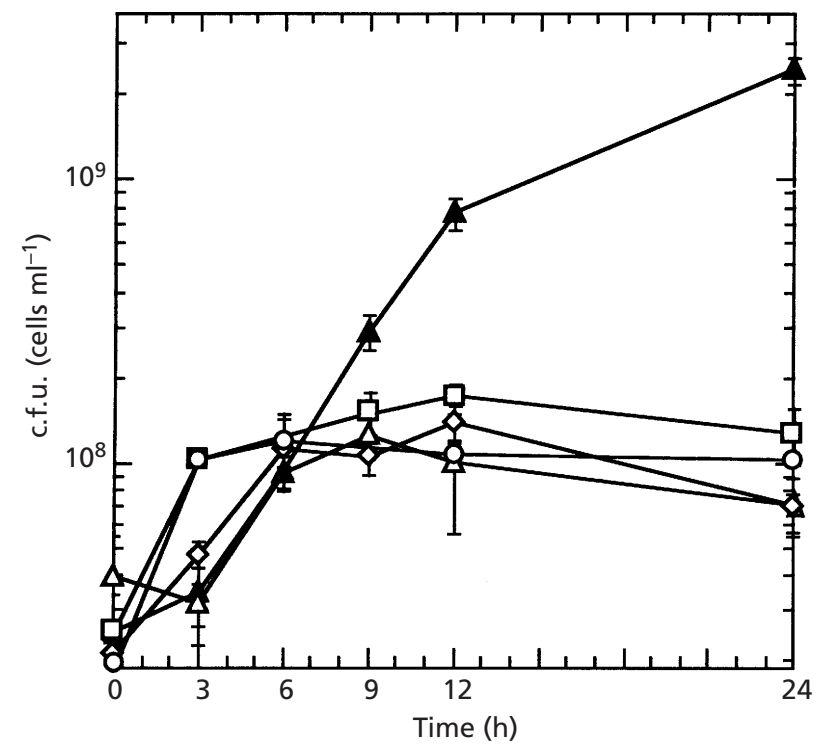

Fig. 6. Growth of TA441 ( $\mathbf{\Lambda})$ and mutant strains ORF1 ${ }^{-}(\square)$, $\mathrm{ORF2}^{-}(\diamond), \mathrm{ORF3}^{-}(\bigcirc)$ and $\mathrm{TesB}^{-}(\triangle)$ on testosterone as the sole carbon source. ORF1- to $\mathrm{TesB}^{-}$are gene disrupted mutants of ORF1 to tes $B$, respectively. The strains were grown in $10 \mathrm{ml} \mathrm{C}$ medium supplemented with $0 \cdot 1 \%(\mathrm{w} / \mathrm{v})$ testosterone.

downstream from tes $B$. These ORFs were designated ORF1 to 3. The deduced N-terminal amino acid sequence of the ORF2 product (SEIALVDRVICAAARAWENDGEVLATGIGL) was almost identical to that of TIP6 (SEIALVDRVIEAAARAWENDGEVLATGIGL; 29 of 30 amino acid residues were the same), one of the testosterone-inducible proteins in C. testosteroni ATCC 11996 (Möbus et al., 1997). The deduced amino acid sequences of ORF1 and ORF2 showed 26.9\% identity with subunit A of glutaconate CoA-transferase, which is involved in glutamate metabolism in Acidaminococcus fermentans, and $22.4 \%$ identity with subunit B, respectively (Mack et al., 1994; Jacob et al., 1997). Glutaconate CoA-transferase produces acetate and glutaconyl-1-CoA from acetyl-CoA and (E)-glutaconate. The deduced amino acid sequence of ORF3 showed about $30 \%$ identity with glutaconyl-CoA hydratase from E. coli (Eichler et al., 1994) and other enoyl-CoA hydratases. Although the homologies are low, all the ORFs have some homology with enzymes for CoA compounds, implying the concern of these ORFs to CoA compounds. The distance between them is very short (16 bp between tes $B$ and ORF1, $12 \mathrm{bp}$ between ORF1 and ORF2, and 1 bp between ORF2 and ORF3), suggesting that tes $B$ and these ORFs may be cotranscribed.

ORF1 to 3 in TA441 were individually disrupted by insertion of a $\mathrm{Km}$-resistance gene, yielding the mutant strains ORF1 ${ }^{-}$to ORF3 ${ }^{-}$, respectively. Fig. 6 shows the growth of TA441 and the mutant strains on testosterone as the sole carbon source. In this experiment, twice the number of the cells (compared to the experiment shown in Fig. 5) were added as the initial inoculum, which

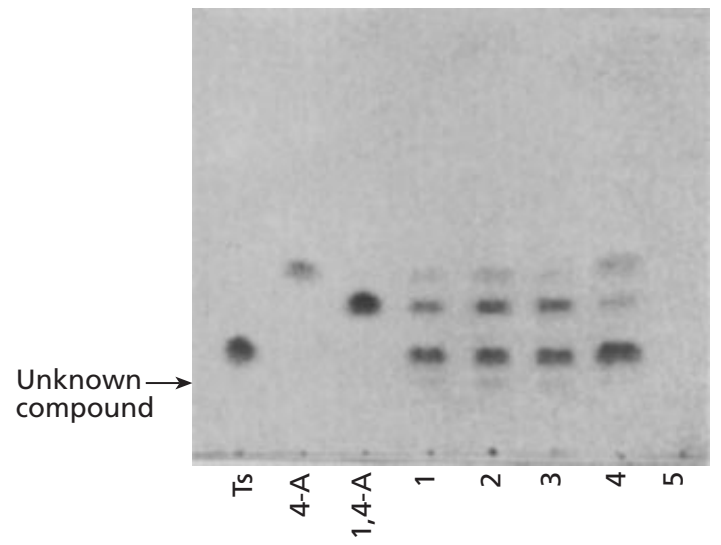

Fig. 7. TLC of cultures of the mutant strains: $\operatorname{Tes}^{-}$(lane 1), ORF1- (lane 2), ORF2 $^{-}$(lane 3), ORF3- (lane 4) and TA441 (lane 5). Cultures grown for $24 \mathrm{~h}$ in the experiment shown in Fig. 6 were extracted with a half volume of ethyl acetate, subjected to TLC (kieselgel 60 F254 plate, Merck KgaA) using benzene/methanol $(19: 1, v / v)$ as the solvent system and detected by UV absorption at $254 \mathrm{~nm}$. Testosterone (Ts), 4androstene-3,17-dione (4-A) and 1,4-androstadiene-3,17-dione $(1,4-\mathrm{A})$ were used as the standards.

probably caused the increase of cell numbers in the initial $6 \mathrm{~h}$. After $6 \mathrm{~h}$, the mutant strains showed little growth on testosterone, indicating that ORF1 to 3 are involved in testosterone metabolism in TA441.

Cultures of the ORF1-, 2- or 3-disrupted mutants grown on testosterone did not show the accumulation of the characteristic yellow colour of meta-cleavage products (data not shown). These results probably indicate that the enzymes encoded by ORF1 to 3 do not act on the meta-cleavage compound produced by TesB. The $\mathrm{ORF}^{-}$mutant showed slight growth on testosterone when it was cultured for several days (Table 2). This suggests that ORF1 is probably involved in the degradation pathway at a step after the cleavage of testosterone into compounds III and IV.

\section{TLC analysis of the culture of the mutants}

TesB is presumed to catalyse the meta-cleavage of 3,4-dihydroxy-9,10-secoandrosta-1,3,5(10)-triene-9,17dione, because the $\mathrm{TesB}^{-}$mutant showed no significant growth on testosterone, suggesting that TesB catalyses a reaction at an early step in the testosterone degradation pathway in TA441. The mutant cultures grown for $24 \mathrm{~h}$ in the experiment shown in Fig. 6 were acidified with $\mathrm{HCl}$, extracted with ethyl acetate, and the ethyl acetate fraction was analysed by TLC (Fig. 7). Accumulation of 4-androstene-3,17-dione, 1,4-androstadiene-3,17-dione and another unknown compound (indicated by an arrow in Fig. 7) was observed in the culture media of all the mutants. 3,4-Dihydroxy-9,10-secoandrosta-1,3,5(10)triene-9,17-dione was not identified. It may be the unknown compound, or may remain in the water fraction, not extracted into the ethyl acetate fraction under the present extraction conditions. All the mutants 


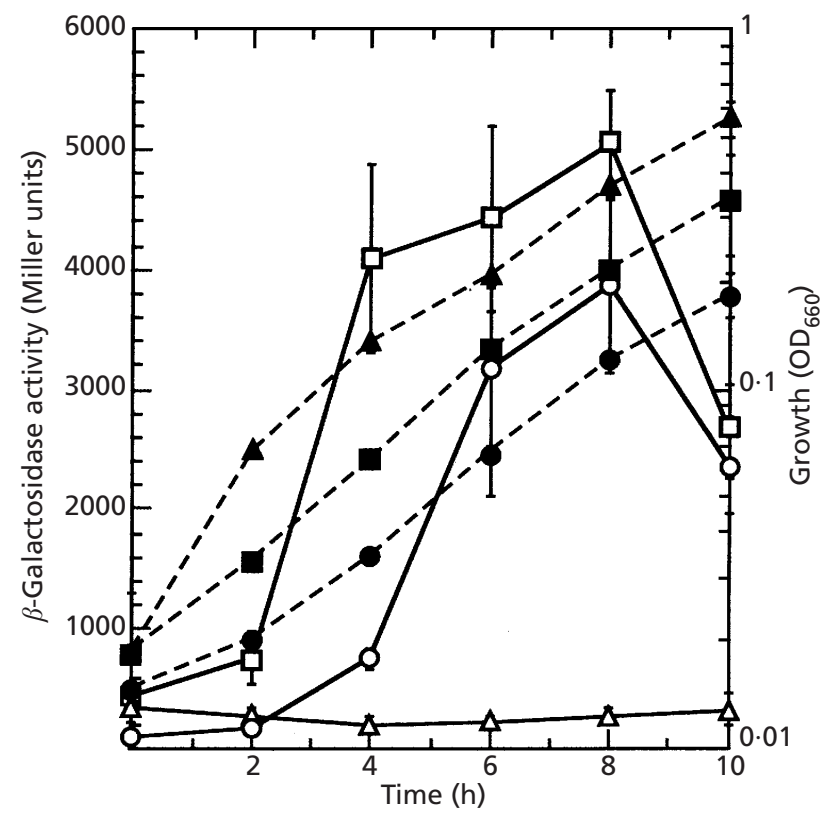

Fig. 8. Transcriptional activity of the tes $B$ promoter in $C$. testosteroni TA441 cultured with testosterone $(O)$, 1,4androstadiene-3,17-dione $(\square)$ or p-hydroxybenzoate $(\triangle$, negative control). TA441 was transformed with pRWtesBp carrying the transcriptional fusion construct tes $B$ :: lac $Z$ (see Fig. 3 ). Changes in the activity of $\beta$-galactosidase, the lac $Z$ gene product, were monitored. The data are means of at least three representative results of independent experiments. Growth of TA441(pRWtesBp) on testosterone; $\mathbf{a}, 1$, 4-androstadiene3,17-dione; $\boldsymbol{\Lambda}, p$-hydroxybenzoate. The error bars of growth data are not presented.

accumulated 4-androstene-3,17-dione and 1,4androstadiene-3,17-dione, which are upstream metabolites of testosterone degradation, indicating that ORF1 to 3 are also involved in testosterone degradation. One possibility for why these compounds were particularly accumulated in all the mutant cultures is that only these compounds are detectable under present analytical conditions. But it seems that these compounds tend to be accumulated in testosterone degradation, as we detected these compounds in the culture of TA441 at an early growth phase (around $8 \mathrm{~h}$ ) and also in the cultures of other newly isolated testosterone-utilizing bacteria grown with testosterone (data not shown).

\section{Induction of TesB}

A putative promoter sequence was found upstream from tesB (133-182 in the sequence under accession number AB040808, indicated by the black arrowhead in Fig. 3). The transcriptional activity of this putative promoter was assessed by monitoring the expression of $\beta$-galactosidase from the lacZ fusion plasmid pR WtesBp (Fig. 3). The result is shown in Fig. 8. Significant induction was observed in TA441 cells grown in the presence of testosterone or its degradation intermediate 1,4androstadiene-3,17-dione. This result implies that ex- pression of tes $B$ is induced by an intermediate compound formed in the course of testosterone degradation.

A putative terminal signal was not found in the sequenced region. Instead, there is another putative ORF just downstream from ORF3, whose stop codon was not found in the sequenced region, indicating that this probable gene cluster continues downstream. Isolation and characterization of genes upstream and downstream from the gene segment tesB to ORF3 are under way.

In this study, we have isolated four genes for testosterone degradation from C. testosteroni and showed that they are induced by a testosterone metabolite and are necessary for testosterone degradation. Our results will effectively facilitate investigation of the entire testosterone degradation pathway of C. testosteroni. Further studies are required to confirm the nature of the substrates and products of the enzymes derived from these cloned genes. Characterization of other genes involved in testosterone degradation will also be important to clarify the features of the testosterone degradation pathway in C. testosteroni.

\section{ACKNOWLEDGEMENTS}

This work was partly supported by a grant from the Eco Molecular Sciences Research Program from RIKEN. M.H. was supported by a grant from the Special Postdoctoral Researchers Program from RIKEN.

\section{REFERENCES}

Abalain, J. H., Di Stefano, S., Amet, Y., Quemener, E., AbalainColloc, M. L. \& Floch, H. H. (1993). Cloning, DNA sequencing and expression of (3-17) $\beta$-hydroxysteroid dehydrogenase from Pseudomonas testosteroni. J Steroid Biochem Mol Biol 44, 133-139.

Abalain, J. H., Di Stefano, S., Abalain-Colloc, M. L. \& Floch, H. H. (1995). Cloning, sequencing and expression of Pseudomonas testosteroni gene encoding $3 \alpha$-hydroxysteroid dehydrogenase. $J$ Steroid Biochem Mol Biol 55, 233-238.

Arai, H., Akahira, S., Ohishi, T., Maeda, M. \& Kudo, T. (1998). Adaptation of Comamonas testosteroni TA441 to utilize phenol: organization and regulation of the genes involved in phenol degradation. Microbiology 144, 2895-2903.

Arai, H., Yamamoto, T., Ohishi, T., Shimizu, T., Nakata, T. \& Kudo, T. (1999). Genetic organization and characteristics of the 3-(3-hydroxyphenyl)propionic acid degradation pathway of Comamonas testosteroni TA441. Microbiology 145, 2813-2820.

Asturias, J. A., Eltis, L. D., Prucha, M. \& Timmis, K. N. (1994). Analysis of three 2,3-dihydroxybiphenyl 1,2-dioxygenases found in Rhodococcus globerulus P6: identification of a new family of extradiol dioxygenases. J Biol Chem 269, 7807-7815.

Birnboim, H. C. \& Doly, J. (1979). A rapid alkaline extraction procedure for screening recombinant plasmid DNA. Nucleic Acids Res 7, 1513-1523.

Choi, K. Y. \& Benisek, W. F. (1988). Nucleotide sequence of the gene for the $\Delta^{5-3}$-ketosteroid isomerase of Pseudomonas testosteroni. Gene 69, 121-129.

Coulter, A. W. \& Talalay, P. (1968). Studies on the microbial degradation of steroid ring A. J Biol Chem 243, 3238-3247. 
Dayhoff, M. O., Schwarts, R. M. \& Orcutt, B. C. (1978). A model of evolutionary change in proteins. In Atlas of Protein Sequence and Structure, vol. 5, suppl. 3, p. 345-352. Edited by M. O. Dayhoff. Washington, DC: National Biomedical Research Foundation.

Eichler, K., Bourgis, F., Buchet, A., Kleber, H. P. \& MandrandBerthelot, M. A. (1994). Molecular characterization of the cai operon necessary for carnitine metabolism in Escherichia coli. Mol Microbiol 13, 775-786.

Florin, C., Kohler, T., Grandguillot, M. \& Plesiat, P. (1996). Comamonas testosteroni 3-ketosteroid- $\Delta^{4}(5 \alpha)$-dehydrogenase: gene and protein characterization. J Bacteriol 178, 3322-3330.

Furukawa, K., Arimura, N. \& Miyazaki, T. (1987). Nucleotide sequence of the 2,3-dihydroxybiphenyl dioxygenase gene of Pseudomonas pseudoalcaligenes. J Bacteriol 169, 427-429.

Genti-Raimondi, S., Tolmasky, M. E., Patrito, L. C., Flury, A. \& Actis, L. A. (1991). Molecular cloning and expression of the $\beta$ hydroxysteroid dehydrogenase gene from Pseudomonas testosteroni. Gene 105, 43-49.

Han, S., Eltis, L. D., Timmis, K. N., Muchmore, S. W. \& Bolin, J. T. (1995). Crystal structure of the biphenyl-cleaving extradiol dioxygenase from a PCB-degrading pseudomonad. Science 270, 976-980.

Hanahan, D. (1983). Studies on transformation of Escherichia coli with plasmids. J Mol Biol 166, 557-580.

Higgins, D. G. \& Sharp, P. M. (1989). Fast and sensitive multiple sequence alignments on a microcomputer. Comput Appl Biosci 5, 151-153.

Hofer, B., Eltis, L. D., Dowling, D. N. \& Timmis, K. N. (1993). Genetic analysis of a Pseudomonas locus encoding a pathway for biphenyl/polychlorinated biphenyl degradation. Gene 130, 47-55.

Jacob, U., Mack, M., Clausen, T., Huber, R., Buckel, W. \& Messerschmidt, A. (1997). Glutaconate CoA-transferase from Acidaminococcus fermentans: the crystal structure reveals homology with other CoA-transferases. Structure 5, 415-426.

Kimbara, K., Hashimoto, T., Fukuda, M., Koana, T., Takagi, M., Oishi, M. \& Yano, K. (1989). Cloning and sequencing of two tandem genes involved in degradation of 2,3-dihydroxybiphenyl to benzoic acid in the polychlorinated biphenyl-degrading soil bacterium Pseudomonas sp. strain KKS102. J Bacteriol 171, 2740-2747.

Kosono, S., Maeda, M., Fuji, F., Arai, H. \& Kudo, T. (1997). Three of the seven $b p h C$ genes of Rhodococcus erythropolis TA421, isolated from a termite ecosystem, are located on an indigenous plasmid associated with biphenyl degradation. Appl Environ Microbiol 63, 3282-3285.
Kulakov, L. A., Delcroix, V. A., Larkin, M. J., Ksenzenko, V. N. \& Kulakova, A. N. (1998). Cloning of new Rhodococcus extradiol dioxygenase genes and study of their distribution in different Rhodococcus strains. Microbiology 144, 955-963.

Kuliopulos, A., Shortle, D. \& Talalay, P. (1987). Isolation and sequencing of the gene encoding $\Delta^{5-3}$-ketosteroid isomerase of Pseudomonas testosteroni: overexpression of the protein. Proc Natl Acad Sci U S A 84, 8893-8897.

Mack, M., Bendrat, K., Zelder, O., Eckel, E., Linder, D. \& Buckel, W. (1994). Location of the two genes encoding glutaconate coenzyme A-transferase at the beginning of the hydroxyglutarate operon in Acidaminococcus fermentans. Eur J Biochem 226, 41-51.

Miller, J. H. (1992). A Short Course in Bacterial Genetics: a Laboratory Manual and Handbook for Escherichia coli and Related Bacteria. Cold Spring Harbor, NY: Cold Spring Harbor Laboratory.

Möbus, E. \& Maser, E. (1998). Molecular cloning, overexpression, and characterization of steroid-inducible $3 \alpha$-hydroxysteroid dehydrogenase/carbonyl reductase from Comamonas testosteroni: a novel member of the short-chain dehydrogenase/ reductase superfamily. J Biol Chem 273, 30888-30896.

Möbus, E., Jahn, M., Schmid, R., Jahn, D. \& Maser, E. (1997). Testosterone-regulated expression of enzymes involved in steroid and aromatic hydrocarbon catabolism in Comamonas testosteroni. J Bacteriol 179, 5951-5955.

Plesiat, P., Grandguillot, M., Harayama, S., Vragar, S. \& MichelBriand, Y. (1991). Cloning, sequencing, and expression of the Pseudomonas testosteroni gene encoding 3-oxosteroid $\Delta^{1}$-dehydrogenase. J Bacteriol 173, 7219-7227.

Sambrook, J., Fritsch, E. F. \& Maniatis, T. (1989). Molecular Cloning: a Laboratory Manual, 2nd edn. Cold Spring Harbor, NY: Cold Spring Harbor laboratory.

Sato, S., Ouchiyama, N., Kimura, T., Nojiri, H., Yamane, H. \& Omori, T. (1997). Cloning of genes involved in carbazole degradation of Pseudomonas sp. strain CA10: nucleotide sequences of genes and characterization of meta-cleavage enzymes and hydrolase. J Bacteriol 179, 4841-4849.

Sih, C. J., Lee, S. S., Tsong, Y. Y. \& Wang, K. C. (1966). Mechanisms of steroid oxidation by microorganisms. VIII. 3,4-Dihydroxy9,10-secoandrosta-1,3,5(10)-triene-9,17-dione, an intermediate in the microbiological degradation of ring A of androst-4-ene-3,17dione. J Biol Chem 241, 540-550.

Vieira, J. \& Messing, J. (1987). Production of single-stranded plasmid DNA. Methods Enzymol 153, 3-11.

Received 20 March 2001; revised 27 July 2001; accepted 14 August 2001. 